\title{
Karakteristik Organoleptik Teh Daun Binahong dengan Penambahan Kayu Manis
}

\author{
Organoleptic Characteristics the Binahong Leaf Herbal Tea with Addition of Cinnamomum
}

\section{Muhammad Yasir, Meittycorfrida Mailoa*, Priscillia Picauly}

\author{
Program Studi Teknologi Hasil Pertanian Fakultas Pertanian Universitas Pattimura \\ Jl. Ir. M. Putuhena Kampus Poka Ambon 97233 \\ *Penulis korespondensi: E-mail: meitymailoa@gmail.com
}

\begin{abstract}
This study was aimed to determine the right concentration of cinnamon addition in the binahong leaf tea based on its sensory characteristics along with its phytochemical compounds composition. A completely randomized experimental design with three levels of cinnamon concentration i.e.; $20 \%, 30 \%$, and $40 \%$ was applied in this research. Results showed that right concentration of cinnamon addition in the binahong leaf tea was $40 \%$ and contained phytochemical compounds such as alkaloids, saponins, flavonoids, steroids, triterpenoids and phenolics.
\end{abstract}

Keywords: binahong leaves, cinnamon, tea drink

\begin{abstract}
ABSTRAK
Penelitian ini bertujuan untuk mendapatkan konsentrasi penambahan kayu manis yang tepat terhadap teh daun binahong berdasarkan sifat organoleptik dan komposisi senyawa fitokimianya. Penelitian ini menggunakan rancangan acak lengkap yang terdiri dari satu faktor yaitu konsentrasi kayu manis dengan tiga taraf perlakuan yaitu; 20\%, 30\%, dan 40\%. Hasil penelitian menunjukkan bahwa teh daun binahong yang terbaik yaitu penambahan kayu manis dengan konsentrasi $40 \%$ yang mengandung senyawa fitokimia alkaloid, saponin, flavonoid, steroid, triterpenoid dan fenolik.
\end{abstract}

Kata kunci: daun binahong, kayu manis, minuman teh

\section{PENDAHULUAN}

Teh merupakan salah satu minuman yang dibuat dari pucuk muda daun teh yang telah mengalami proses pengolahan tertentu. Teh sangat popular dan digemari oleh masyarakat Indonesia. Manfaat yang dihasilkan dari minuman teh adalah memberi rasa segar dan dapat memulihkan kesehatan badan. Selain dari daun teh, minuman teh juga dapat dibuat dari daun-daunan yang lain, salah satunya daun yang memiliki manfaat kesehatan yaitu daun binahong.

Binahong merupakan salah satu tanaman yang berkhasiat sebagai obat tradisional yang berasal dari daratan cina dengan nama asalnya adalah dheng shan chil. Tanaman binahong yang umumnya dijadikan sebagai obat adalah daunnya.
Tanaman ini mempunyai banyak khasiat dalam menyembuhkan berbagai macam penyakit ringan maupun berat (Suci et al., 2013). Bukan hanya daunnya, namun seluruh bagian dari tanaman binahong dapat digunakan dalam keperluan pengobatan. Hasil penelitian Khunaifi (2010), menunjukkan bahwa hasil uji fitokimia ekstrak daun binahong ditemukan senyawa polifenol, alkaloid dan flavonoid yang berfungsi sebagai anti bakteri. Binahong yang digunakan dalam bahan dasar daun binahong menjadi lebih baik jika adanya tanaman obat yang lain sebagai penambahan dalam minuman herbal salah satu tanaman obat adalah kayu manis.

Kayu manis merupakan salah satu rempah yang memiliki efek farmakologis. Khasiat kayu manis didukung dengan beberapa penelitian yang 
dilakukan oleh Pratiwi (2011), menyatakan bahwa kayu manis merupakan bahan makanan sumber antioksidan yang mengandung alkaloid, flavonoid, tanin, dan minyak atsiri. Penelitian yang dilakukan Anjani et al. (2015), bahwa dengan penambahan filtrat kayu manis memberikan pengaruh pada total fenol, aktivitas antioksidan, $\mathrm{pH}$ dan warna pada produk teh herbal kulit salak yang bermanfaat bagi pengobatan diabetes melitus. Kayu manis biasanya dimanfaatkan sebagai bahan pemberi aroma dan citarasa dalam makanan dan minuman. Oleh karena itu, kayu manis berpotensi untuk diolah menjadi minuman teh. Tasia (2014), tanaman cincau hitam, daun pandan dan kayu manis telah terbukti memiliki beberapa senyawa bioaktif yang bermanfaat bagi tubuh diantaranya adalah senyawa polifenol, alkaloid, sinamaldehid, dan lain-lain, sehingga sangat bermanfaat bagi kesehatan tubuh. Senyawa-senyawa yang terkandung dalam kayu manis menjadikan kayu manis berpotensi sebagai tanaman yang berkhasiat untuk kesehatan dan juga berpotensi sebagai campuran dengan daun binahong dalam pembuatan teh yang juga bermanfaat untuk kesehatan.

Berdasarkan uraian tersebut maka telah dilakukan penelitian tentang pembuatan teh daun binahong dengan penambahan kayu manis. Penelitian ini bertujuan untuk mendapatkan konsentrasi penambahan kayu manis yang tepat terhadap teh daun binahong berdasarkan sifat organoleptik dan komposisi senyawa fitokimianya.

\section{METODOLOGI PENELITIAN}

\section{Bahan}

Bahan untuk pembuatan teh binahong adalah daun binahong berwarna hijau tua dengan batang dan tulang daun berwarna merah dan kayu manis yang diperoleh dari Pulau Banda.

\section{Pelaksanaan Penelitian}

\section{Pembuatan Teh Binahong}

Dalam tahapan awal, daun binahong disortir atau dipilih yang baikdan dipisahkan dari yang rusak, setelah itu dicuci bersih dengan air mengalir dan kemudian dikeringkan. Selanjutnya pada tahap perebusan, daun binahong direbus dengan air 1000 $\mathrm{ml}$ selama 15 menit. Setelah direbus, dicampur kayu manis sesuai perlakuan yaituk konsentrasi kayu manis 20\%, 30\%, dan 40\%. Setelah kedua bahan dicampur kemudian disaring untuk memperoleh teh daun binahong.

\section{Pengamatan}

Pengamatan yang dilakukan pada teh daun binahong yaitu uji organoleptik berdasarkan mutu hedonik yang meliputi; rasa, aroma, dan warna. Perlakuan terbaik berdasarkan uji organoleptik. Selanjutnya diuji senyawa fitokimia meliputi uji alkoloid, saponin, flavonoid, triterpenoid, steroid, dan fenolik (Harborne, 1998).

\section{Analisis Data}

Data hasil penelitian dianalisis secara statistik menggunakan analisis keragaman, bila terdapat perbedaan yang nyata atau sangat nyata maka pengujian dilanjutkan dengan uji beda nyata terkecil (BNT, $\alpha=0,05)$.

\section{HASIL DAN PEMBAHASAN}

\section{Rasa}

Rasa merupakan salah satu indikator terpenting dalam penentuan diterima atau tidaknya suatu produk. Rasa dapat ditentukan melalui beberapa indera mulut dengan cecapan dan rangsangan mulut (Winarno, 2008). Respon penerima sangat dipengaruhi oleh indera pengecap (lidah) pada masing-masing orang. Suatu produk akan tidak berarti walaupun secara uji kimia, fisik, dan nilai gizinya tinggi, tetapi bila rasanya tidak enak akan sulit diterima oleh konsumen.

Hasil uji organoleptik teh daun binahong menunjukkan bahwa penambahan konsentrasi kayu manis terhadap rasa secara statistik tidak memberi pengaruh nyata. Penilaian panelis terhadap parameter rasa teh daun binahong berada pada skala 2,4-2,64 atau tidak terasa pahit.

Sebagian besar panelis menilai rasa tidak pahit pada teh daun binahong. Penilaian rasa tidak pahit diduga karena kayu manis yang digunakan memiliki rasa yang tidak pahit. Menurut Sundari (2002), bahwa kayu manis adalah satu jenis rempah-rempah yang banyak digunakan sebagai bahan pemberi aroma dan cita rasa dalam makanan dan minuman.

Kayu manis yang ditambahkan dalam minuman bukan hanya sebagai flavor, namun juga untuk mendapatkan tambahan nilai fungsional dari minuman yang dihasilkan. 
Tabel 1. Hasil uji organoleptik teh daun binahong

\begin{tabular}{cccc}
\hline Perlakuan & Rasa & Aroma & Warna \\
\hline Kayu manis 20\% & Tidak pahit $(2,60 \mathrm{a})$ & Harum $(3,10 \mathrm{a})$ & Tidak coklat $(2,80 \mathrm{a})$ \\
Kayu manis $30 \%$ & Tidak pahit $(2,64 \mathrm{a})$ & Harum $(3,40 \mathrm{a})$ & Agak coklat $(3,10 \mathrm{ab})$ \\
Kayu manis $40 \%$ & Tidak pahit $(2,40 \mathrm{a})$ & Harum $(3,60 \mathrm{a})$ & Agak coklat $(3,50 \mathrm{~b})$ \\
\hline
\end{tabular}

Keterangan: Notasi yang sama pada kolom yang sama menunjukkan tidak ada perbedaan yang nyata pada uji BNT ( $\alpha=$ $0,05)$

\section{Aroma}

Aroma merupakan bau yang ditimbulkan oleh rangsangan kimia yang tercium oleh syarafsyaraf olfaktori yang berada dalam rongga hidung ketika makanan masuk ke dalam mulut. Aroma yang dihasilkan oleh makanan atau bahan tertentu dapat dideteksi melalui indera penciuman. Reaksi dari makanan yang mempengaruhi konsumen sebelum konsumen menikmati makanan adalah aromanya dan aroma yang dihasilkan akan baik jika bahan yang digunakan mudah menguap.

Hasil uji organoleptik teh daun binahong menunjukkan bahwa penambahan konsentrasi kayu manis terhadap aroma secara statistik tidak memberi pengaruh nyata. Penilaian panelis terhadap parameter aroma berada pada skala 3,13,6 atau secara deskriptif teh daun binahong beraroma agak harum.

Rata-rata panelis menilai aroma agak harum pada teh daun binahong dikarenakan adanya penambahan kayu manis yang merupakan salah satu rempah-rempah yang digunakan sebagai campuran masakan maupun minuman yang berfungsi untuk memberi aroma serta membangkitkan selera. Hasil penelitian Haras et al. (2017), berdasarkan uji sensori panelis menilai teh daun binahong yang dihasilkan tidak memiliki aroma. Untuk itu dalam penelitian ini, penambahan kayu manis yang dapat mempengaruhi aroma teh daun binahong.

Penambahan kayu manis pada minuman dapat membuat aroma semakin tercium karena kayu manis bersifat mudah menguap dan memiliki bau yang khas. Menurut Rismunandar (1993), kayu manis menghasilkan aroma yang berasal dari minyak atsiri yang terdapat pada seluruh bagian tanaman kayu manis. Penambahan kayu manis adalah selain dapat memberikan aroma yang khas pada minuman maupun makanan, juga dapat memberikan manfaat kesehatan.

\section{Warna}

Warna merupakan karakteristik yang menentukan penerimaan atau penolakan suatu produk oleh konsumen. Warna juga merupakan atribut penting, walaupun suatu produk bernilai gizi tinggi dan rasanya yang enak namun jika warna yang dihasilkan tidak menarik maka menyebabkan produk kurang diminati.

Hasil uji organoleptik teh daun binahong menunjukkan bahwa penambahan konsentrasi kayu manis terhadap warna secara statistik memberikan pengaruh nyata. Penilaian panelis terhadap parameter rasa berada pada skala 2,8-3,5 atau secara deskriptif teh daun binahong memiliki warna tidak coklat sampai agak coklat.

Uji mutu hedonik pada minuman teh daun binahong dengan perlakuan konsentrasi kayu manis $20 \%$, panelis paling banyak memilih dengan warna tidak cokelat, namun pada perlakuan dengan konsentrasi kayu manis 30\% dan $40 \%$ panelis paling banyak memilih dengan warna agak cokelat. Untuk itu semakin tinggi konsentrasi kayu manis maka teh daun binahong semakin berwarna coklat. Hal ini dikarenakan adanya kandungan senyawa fenol berupa tanin yang menyebabkan warna coklat pada teh daun binahong. Pratiwi (2011), menyatakan bahwa kayu manis merupakan bahan makanan sumber antioksidan yang mengandung tanin. Hal ini sesuai dengan penelitian Anjani et al. (2015), yang menyatakan bahwa adanya penambahan konsentrasi filtrat kayu manis yang semakin tinggi maka akan meningkatkan total fenol produk sehingga menimbulkan warna coklat pada produk yang dihasilkan.

\section{Perlakuan Terbaik}

Secara keseluruhan pengujian organoleptik terhadap teh daun binahong dengan penambahan konsentrasi kayu manis pada setiap perlakuan yang meliput rasa dan aroma tidak berbeda, sedangkan yang menunjukkan perbedaan hanya pada parameter warna. Maka pemilihan perlakuan 
terbaik yaitu pada konsentrasi $40 \%$ dikarenakan rasa yang tidak pahit, aromanya yang agak harum dan warna yang dihasilkan adalah agak coklat.

\section{Fitokimia Teh Daun Binahong}

Hasil uji senyawa fitokimia pada teh daun binahong berupa alkoloid, saponin, flavonoid, triterpenoid, steroid, dan fenolik pada teh daun binahong menunjukkan positif ditandai dengan terbentuknya warna kecuali saponin yang ditandai dengan adanya busa.

Senyawa alkaloid memiliki efek berupa pemicu sistem syaraf, antimikroba, obat penyakit jantung dan lainnya (Rohyani et al., 2015). Flavonoid merupakan antioksidan yang menetralisir radikal bebas yang meyerang sel-sel tubuh. Flavonoid selain ditemukan dalam buahbuahan juga dapat ditemukan pada daun, salah satunya adalah daun binahong. Menurut Astuti et al. (2011), begitu pentingnya distribusi senyawa saponin dari tanaman karena memiliki potensi untuk mengobati berbagai penyakit dan senyawa saponin yang ada dalam daun binahong berguna sebagai antimikroba dan perangsang pertumbuhan sel-sel baru pada luka. Untuk senyawa fenolik yang ada dalam minuman binahong memiliki peran yang baik bagi kesehatan dimana senyawa ini banyak digunakan sebagai antioksidan, antimikroba, antikanker maupun lainnya. Pada daun binahong juga ditemukan adanya senyawa triterpenoid yang memiliki peran bagi kesehatan diantaranya sebagai antidiabetes, sitotoksik terhadap sel tumor, malaria, dan gangguan menstruasi. Seluruh bagian tanaman dari binahong yaitu bunga, daun, batang dan umbi mengandung senyawa fenol, flavonoid, saponin, terpenoid, steroid dan alkaloid.

Secara keseluruhan senyawa-senyawa yang ada dalam teh bukan hanya berasal dari daun binahong namun kayu manis juga memiliki peran dalam menyumbang senyawa yang terkandung dalam minuman, dikarenakan kayu manis memiliki kandungan senyawa kimia berupa fenol, terpenoid dan saponin yang merupakan sumber antioksidan (Rafita, 2015). Hasil penelitian Qamari et al. (2016), menunjukkan bahwa kayu manis terdapat senyawa alkaloid, steroid, flavonoid, saponin, fenol dan tanin.

\section{KESIMPULAN}

Hasil uji organoleptik menunjukkan teh daun binahong dengan konsentrasi kayu manis $40 \%$ sebagai perlakuan terbaik karena rasa yang dihasilkan tidak pahit, baunya yang agak harum serta warna yang dihasilkan berwarna agak cokelat. Minuman teh daun binahong mengandung senyawa fitokimia berupa alkaloid, saponin, flavonoid, triterpenoid, steroid dan fenolik.

\section{DAFTAR PUSTAKA}

Anjani, P.P., S. Andrianty, dan T.D. Widyaningsih. 2015. Pengaruh penambahan pandan wangi dan kayu manis pada teh herbal kulit salak bagi penderita diabetes. Jurnal Pangan dan Agroindustri 3: 203-214.

Astuti, S.M., M.A.M, Sakinah, R.B.M, Andayani, and A. Risch. 2011. Determination of saponin compound from Anredera cordifolia (Ten) Steenis plant (Binahong) to potential treatment for several diseases. Journal of Agricultural Science 3: 224-232.

Astuti, S.M. 2013. Skirining fitokimia dan uji aktivitas antibiotika ekstrak etanol daun, batang, bunga dan umbi tanaman binahong (Anredera cordifolia (Ten) Steenis). Balai Besar Pengujian Mutu dan Sertifikasi Obat Hewan 19: 61-68.

Haras, M.S., J.R. Assa, dan T. Langi. 2017. Tingkat penerimaan konsumen terhadap teh daun binahong (Anredera cordifolia (Ten.) Steenis) pada variasi suhu dan waktu penyeduhan. Jurnal Cocos 1: 1-7.

Harborne, J.B. 1998. Phytochemical Methods: A Guide to Modern Techniques of Plant Analysis. Third Edition. Chapman and Hall. London.

Khunaifi, M. 2010. Uji Aktifitas Antibakteri Ekstrak Daun Binahong (Anredera cordifolia (Ten). Steenis) Terhadap Bakteri Staphylococcus aureus dan Pseudomonas aeruginosa. Skripsi. Sains dan Teknologi. Universitas Islam Negeri (UIN) Maulana Malik Ibrahim. Malang.

Pratiwi, I.Y. 2011. Pengaruh Variasi Maltodekstrin terhadap Kualitas Minuman Serbuk Instan Kayu Manis (Cinnamomun burnanii BI.). Tesis. Universitas Atma Jaya. Yogyakarta.

Mubarak, Z., S. Chismirina, dan C.A. Qamari. 2016. Aktivitas antibakteri (Cinnamomum burmannii) ekstrak kayu manis terhadap 
pertumbuhan Enterococcus faecalis. Jurnal Cakradonya Dent 8: 1-17.

Rafita, I.D. 2015. Pengaruh Ekstrak Kayu Manis (Cinnamomun burnanii) Terhadap Gambaran Histopatologi Dan Kadar SGOT SGPT Hepar Tikus Yang Diinduksikan Parasetamol. Skripsi. Fakultas Matematika dan Ilmu Pengetahuan Alam. Universitas Negeri Semarang. Semarang.

Sundari, E. 2002. Pengambilan Minyak Atsiri Dan Oleoresin Dari Kulit Kayu Manis. Tesis. Institut Teknologi Bandung. Bandung.
Tasia, W.R.N., dan T.D. Widyaningsih. 2014. Potensi cincau hitam (Mesona palustris BI.), daun pandan (Pandanus amaryllifolius) dan kayu manis (Cinnamomun burmannii) sebagai bahan baku minuman herbal fungsional. Jurnal Pangan dan Agroindustri 2: 128-136.

Winarno, F.G. 2008. Kimia Pangan dan Gizi. MBrio Press. Bogor. 